breath-hold magnetic resonance coronary angiography. Circulation 1993;87:94-104.

3. Moshage WE, Achenbach S, Seese B, Bachmann K, Kirchgeorg M. Coronary artery stenoses: three-dimensional imaging with electrocardiographically triggered, contrast agentenhanced, electron-beam CT. Radiology 1995;196:707-14.

4. Roberts W, Dicicco B, Waller B, Kishel J, McManus B, Dawson $S$, et al. Origin of the left main from the right coronary artery or from the right sinus with intramyocardial tunneling to the left side: the case against clinical significance of myocardial bridge or coronary tunnel. Am Heart J 1982; 104:303-5.

5. Fallavollita JA, Brody AS, Bunnell IL, Kumar K, Canty JM. Fast computed tomography detection of coronary calcification in the diagnosis of coronary artery disease. Circulation 1994;89:285-90.

\title{
SALMONELLA PROSTHETIC VALVE ENDOCARDITIS
}

\author{
Norihide Fukushima, MD, ${ }^{a}$ Namiko Ishikawa, MD, ${ }^{a}$ Yasuhisa Shimazaki, MD, ${ }^{a}$ Kazuhiro Taniguchi, MD, ${ }^{a}$ \\ Masahiro Tanemura, MD, ${ }^{\mathrm{a}}$ Akihumi Matsuyama, MD, ${ }^{\mathrm{b}}$ Yuji Matsuzawa, MD, ${ }^{\mathrm{b}}$ and Hikaru Matsuda, MD, ${ }^{\mathrm{a}}$ \\ Osaka, Japan
}

Salmonella endocarditis has been characterized by its destructive process and malignant clinical course. ${ }^{1} \mathrm{Al}-$ though an increasing number of such infections have been evident in recent years, Salmonella prosthetic valve endocarditis (PVE) is still rare. ${ }^{2-4}$ Only seven case reports have appeared in the English literature up to now. Because of its rarity and unusual clinical course, we describe the eighth case of Salmonella PVE in a patient who underwent rereplacement of the aortic and mitral prosthetic valves and simultaneous cholecystectomy. We also review the previous cases reported in the literature.

Case report. A 58-year-old man was admitted on an emergency basis on October 1, 1994, with fever, chills, and weakness of 3 days' duration. He had undergone aortic and mitral replacement, tricuspid annuloplasty, and closure of an atrial septal defect in 1981 at 45 years of age. He had two brothers who had died of enteric typhus. On admission, his temperature was $42.0^{\circ} \mathrm{C}$ and blood pressure was $86 / 60 \mathrm{~mm} \mathrm{Hg}$. He had normal regular prosthetic valve sounds at 76 beats $/ \mathrm{min}$. The white blood cell count was $12,100 / \mathrm{mm}^{3}$ with $61 \%$ segmented polymorphonuclear white cells and bands of $15 \%$ but with no eosinophils. The chest $x$-ray film showed moderate cardiomegaly and the electrocardiogram showed incomplete right bundle branch block with normal sinus rhythm. After intravenous antibiotics were given, the white blood cell count decreased, the eosinophil count increased, and spiking fevers disappeared. Because clinical examinations showed

From the First Department of Surgery a and the Second Department of Medicine, ${ }^{\text {b }}$ Osaka University Medical School, Osaka, Japan.

Received for publication Oct. 30, 1995; accepted for publication Oct. 31, 1995.

Address for reprints: Hikaru Matsuda, MD, Professor, First Department of Surgery, Osaka University Medical School, 2-2 Yamada-oka, Suita, Osaka 565, Japan.

J Thorac Cardiovase Surg 1996;112:840-2

Copyright (C) 1996 by Mosby-Year Book, Inc.

$0022-5223 / 96 \$ 5.00+0 \quad \mathbf{1 2 / 5 4 / 7 0 3 2 3}$ no evidence of infectious endocarditis, antibiotics were discontinued on day 28 after admission. Five days later, his body temperature elevated again with chills. The white blood cell count increased and the eosinophil count decreased. Salmonella typhimurium was isolated from the blood three times after recurrent fever. A transesophageal echocardiogram (TEE) revealed a highly mobile echo mass attached to the anulus of the mitral prosthetic valve and an immobile echo mass on the subvalvular position of the aortic valve.

After 66 days of hospitalization, he underwent rereplacement of the aortic and mitral prosthetic valves and simultaneous cholecystectomy. The aortic prosthetic valve did not appear grossly infected but had moderate sized subvalvular pannus formation. A vegetation was found on the anterior anulus of the mitral valve. The mitral and aortic prostheses were replaced with a CarboMedics bileaflet prosthesis $(29 \mathrm{~mm}$ in diameter; CarboMedics, Inc., Austin, Tex.) and a St. Jude Medical prosthesis (25 $\mathrm{mm}$ in diameter; St. Jude Medical, Inc., St. Paul, Minn.). After closure of the chest, the gallbladder was removed in the usual fashion. Gall stones were found in the gallbladder, but intraoperative choledochography revealed no choledochal stones. The patient was moved to the intensive care unit in a stable hemodynamic condition. Microscopic examination of the tissue surrounding the mitral prosthetic valve showed diffuse infiltration of lymphocytes and neutrophils with clusters of micrococci. The gallbladder showed mild cellular infiltration. Culture of the vegetation and bile grew Micrococcus but no Salmonella. The concentrations of sulbactam and cefoperazone in the serum, the wall of the gallbladder, and the bile in the gallbladder were four times higher than the minimum inhibitory or bactericidal concentration for $S$. typhimurium, resulting in a failure to isolate Salmonella from these specimens. Imipenem, to which not only Salmonella but Micrococcus was sensitive, was given intravenously for 6 weeks after the operation. A TEE on postoperative day 35 revealed no vegetation, and he was discharged on postoperative day 36 . He had no evidence of recurrent infection during 1 year of follow-up. 
Table I. Characteristics of the previous and present cases of preoperative Salmonella PVE

\begin{tabular}{|c|c|c|c|c|c|c|c|c|c|}
\hline Case & Author & Year & $\begin{array}{l}\text { Age, } \\
\text { sex }\end{array}$ & Salmonella species & $\begin{array}{c}\text { Preexisting } \\
\text { heart disease }\end{array}$ & $\begin{array}{c}\text { Preexisting } \\
\text { prosthetic valve } \\
\text { (position of } \\
\text { valves) }\end{array}$ & $\begin{array}{l}\text { Duration from } \\
\text { the first } \\
\text { replacement to } \\
\text { onset of } \\
\text { endocarditis } \\
\text { (yr) }\end{array}$ & $\begin{array}{c}\text { Antibiotic } \\
\text { therapy }\end{array}$ & $\begin{array}{c}\text { Total } \\
\text { duration of } \\
\text { antibiotic } \\
\text { therapy } \\
\text { (days) }\end{array}$ \\
\hline 1 & Weinstein & 1965 & $44, \mathrm{M}$ & S. schwarzengrund & $\mathrm{R}(\mathrm{M}$ and $\mathrm{A})$ & Hufnagel (A) & 4 & $\mathrm{CP}$ & 27 \\
\hline 2 & Fraser & 1967 & $56, \mathrm{~F}$ & S. hirschfeldii & $\mathrm{R} ?(\mathrm{~A})$ & Bahnson (A) & 4 & $\begin{array}{l}\mathrm{PC}, \mathrm{CP}, \\
\text { ABPC, SM, } \\
\mathrm{MC}\end{array}$ & Unknown \\
\hline 3 & Yamamoto & 1974 & $50, \mathrm{~F}$ & $\begin{array}{l}\text { S. choleraesuis } \\
\text { S. enteritidis } \\
\quad \text { (groupD) }\end{array}$ & $\mathrm{R}(\mathrm{M})$ & Unknown (M) & 3 & $\mathrm{ABPC}, \mathrm{TC}$ & 54 \\
\hline 4 & Shanson & 1977 & $52, \mathrm{M}$ & S. enteritidis & $\mathrm{S}(\mathrm{A})$ & $\begin{array}{l}\text { Starr-Edwards } \\
\text { (A) }\end{array}$ & 3 & $\begin{array}{l}\text { GM, CEZ, CP, } \\
\text { ABPC, } \\
\text { mecillinam }\end{array}$ & 48 \\
\hline 5 & Bassa & 1989 & $\begin{array}{l}\mathrm{NA} \\
\mathrm{NA}\end{array}$ & S. nontyphi & NA & NA & NA & NA & NA \\
\hline 6 & Choo & 1992 & $62, \mathrm{~F}$ & S. heidelberg & $\mathrm{R}(\mathrm{M}$ and $\mathrm{T})$ & $\begin{array}{l}\text { Hancock } \\
\quad(\mathrm{M} \text { and } \mathrm{T})\end{array}$ & 9 and 7 & $\begin{array}{l}\text { CTX, ABPC } \\
\text { GM }\end{array}$ & 81 \\
\hline 7 & Lee & 1994 & $42, \mathrm{M}$ & Group B & $\mathrm{R}(\mathrm{M}$ and $\mathrm{A})$ & $\begin{array}{c}\text { Björk-Shiley } \\
\text { (M and A) }\end{array}$ & 19 & $\begin{array}{l}\text { VCM, netilmi- } \\
\text { cin, CTX }\end{array}$ & $>100$ \\
\hline 8 & $\begin{array}{c}\text { Present } \\
\text { case }\end{array}$ & 1996 & $49, \mathrm{M}$ & S. typhimurium & $\mathrm{R}(\mathrm{M}$ and $\mathrm{A})$ & $\begin{array}{l}\text { Björk-Shiley } \\
\text { (M and A) }\end{array}$ & 13 & $\begin{array}{l}\text { PIPC, SBT/ } \\
\text { CPZ, GM, } \\
\text { ABPC }\end{array}$ & 64 \\
\hline
\end{tabular}

$\bar{R}$ Rheumatic; $M$, mitral; $A$, aortic; $S$, syphilitic; $T$, tricuspid; $N A$, not available; $C P$, chloramphenicol; $P C$, penicillin; $S M$, streptomycin; $A B P C$, ampicillin; $M C$, minocycline; $T C$, tetracycline; $G M$, gentamicin; $C E Z$, cefazolin; $V C M$, vancomycin; $C T X$, ceftriaxone; $P I P C$, piperacillin; $S B T$, sulbactam; $C P Z$, cefoperazone.

Table II. Surgical treatment and outcome of the previous and present cases of Salmonella PVE

\begin{tabular}{|c|c|c|c|c|c|c|c|}
\hline Case & Surgical treatment & $\begin{array}{l}\text { New prosthetic valves } \\
\text { (position of valves) }\end{array}$ & $\begin{array}{l}\text { Vegetation } \\
\text { (position of } \\
\text { valves) }\end{array}$ & $\begin{array}{c}\text { Postop. } \\
\text { antibiotic } \\
\text { therapy }\end{array}$ & $\begin{array}{c}\text { Duration of } \\
\text { postoperative } \\
\text { antibiotics } \\
\text { therapy (days) }\end{array}$ & Complications & Outcome \\
\hline 1 & None & & Aortic abscess & None & 48 & Dissecting aneurysm & Died (preop.) \\
\hline 2 & Re-AVR & McGovern (A) & Yes (A) & None & 45 & $\begin{array}{l}\text { Cerebral emboli } \\
\text { (preop.) }\end{array}$ & Died (POD1) \\
\hline 3 & Re-MVR & Kay-Shiley (M) & Yes (M) & $\mathrm{ABPC}, \mathrm{SM}$ & 120 & $\begin{array}{l}\text { Cerebral emboli } \\
\text { (preop.); fever and } \\
\text { isolation of Salmo- } \\
\text { nella from stool } \\
\text { postop. }\end{array}$ & Alive \\
\hline 4 & Re-AVR & Björk-Shiley (A) & Yes (A) & NA & NA & $\begin{array}{c}\text { Cerebral emboli, } \\
\text { pancytopenia }\end{array}$ & Died \\
\hline 5 & None & & Yes (?) & NA & NA & None & Died (preop.) \\
\hline 6 & $\begin{array}{l}\text { AVR, Re-MVR, } \\
\text { Re-TVR }\end{array}$ & $\begin{array}{l}\text { St. Jude Medical (A, } \\
\text { M, and T) }\end{array}$ & Yes $(\mathrm{T})$ & CTX, CPFX & 102 & None & Alive \\
\hline 7 & None & & $\begin{array}{l}\text { Yes (A and } \\
\text { M) }\end{array}$ & None & none & None & Died (preop.) \\
\hline 8 & $\begin{array}{l}\text { Re-AVR, Re- } \\
\text { MVR }\end{array}$ & $\begin{array}{l}\text { St. Jude Medical (A), } \\
\text { CarboMedics (M) }\end{array}$ & Yes (M) & $\begin{array}{l}\text { IPM, BAC, } \\
\text { DFLX }\end{array}$ & 156 & None & Alive \\
\hline
\end{tabular}

$A V R$, Aortic valve replacement; $M V R$, mitral valve replacement; $T V R$, tricuspid valve replacement; $A$, aortic; $M$, mitral; $T$, tricuspid; $N A$, not available; $A B P C$, ampicillin; $S M$, streptomycin; $C T X$, ceftriaxone; $C P F X$, ciprofloxacin; $I P M$, imipenam; $B A C$, sulfamethoxazole and trimethaprim; $D F L X$, difloxacin.

Comment. Endocarditis resulting from Salmonella is rare but has a high mortality rate even when treated with intravenous administration of antibiotics. ${ }^{1}$ Seven cases of Salmonella PVE have been reported in the English liter- ature (Table I) ${ }^{2-4}$ Many types of Salmonella were isolated from the blood, valve, and aortic wall (Table I). All six patients were treated with intravenous antibiotic therapy that achieved an adequate serum bactericidal level for 34 
to 100 days; however, rereplacement of valves was considered in all and three died before the operation. Four patients underwent rereplacement of the prosthetic valve and only two survived the operation (Table II). No patient underwent simultaneous cholecystectomy. Our patient represents the eighth reported case of Salmonella prosthetic valve infection and only the third to have survived. Because of high mortality and recurrence rates of Salmonella PVE, early surgical intervention should be considered. For a diagnosis of PVE, transthoracic echocardiography did not disclose a vegetation before the operation in five of seven cases of Salmonella PVE, whereas TEE could detect a vegetation in both cases in which TEE was done. TEE should be done if PVE is suspected.

In Salmonella PVE with a possible infectious origin of the gallbladder, it is still controversial to perform simultaneous operations. The previous patients did not undergo simultaneous cholecystectomy. Salmonella species can persist in the gastrointestinal system, especially in the gallbladder, in carriers who are symptom-free. It is difficult to eradicate Salmonella in patients with gallstones or scarring of the biliary tree even after intravenous antibiotics. ${ }^{5}$ Some patients with Salmonella infection resistant to intravenous antibiotic therapy required cholecystectomy to eradicate the carrier state. ${ }^{5}$ One of two patients who survived after surgery for Salmonella PVE had recurrent fever after the operation, and Salmonella was isolated from his stool on the fifth postoperative day. In the Japanese literature, one patient with Salmonella PVE who survived after rereplacement of two prostheses had cholecystitis after the operation. Therefore simultaneous cholecystectomy should be considered in Salmonella PVE, especially in case of bile duct infection or gallstones, as in the present patient.

In summary, we described the eighth case of Salmonella PVE. Rereplacement of the aortic and mitral prosthetic valves and simultaneous cholecystectomy were done, without recurrence of the infection during 1 year of follow-up.

\section{REFERENCES}

1. Cohen PS, Maguire JH, Weinstein L. Infective endocarditis caused by Gram-negative bacteria: a review of the literature, 1945-1977. Prog Cardiovasc Dis 1980;22:205-42.

2. Yamamoto N, Magidson O, Posner C, Mendez MA, Zubiate P, Kay JH. Probable Salmonella endocarditis treated with prosthetic valve replacement: a case report. Surgery 1974;76: 678-81.

3. Choo PW, Gantz NM, Anderson C, Maguire H. Salmonella prosthetic valve endocarditis. Diagn Microbiol Infect Dis 1992; 15:273-6.

4. Lee Y, Lai L, Shyu K, Kuan P, Lien W. Salmonella prosthetic valve endocarditis: a case report. J Vase Dis 1994;45:245-7.

5. Neil MA, Opal SM, Heelan J, et al. Failure of ciplofloxacin to eradicate convalescent fecal excretion after acute salmonellosis: experience during an outbreak in health care workers. Ann Intern Med 1991;114:195-9.

\title{
UNUSUAL COMPLICATION SEVEN YEARS AFTER SUCCESSFUL AORTIC RECOARCTATION REPAIR WITH A DACRON GRAFT: ACUTE THROMBOEMBOLIC LEG ISCHEMIA CAUSED BY A MOBILE THROMBUS AT THE DISTAL SUTURE LINE
}

\author{
R. Berzins, MD, ${ }^{\text {a }}$ C. H. Attenhofer, MD, ${ }^{\mathrm{b}}$ L. K. von Segesser, MD, ${ }^{\mathrm{c}}$ M. Hauser, MD, ${ }^{\mathrm{d}}$ M. Turina, MD, ${ }^{\mathrm{c}}$ and

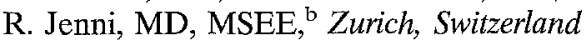

Uncorrected coarctation of the aorta is associated with a substantially shortened life expectancy. ${ }^{1}$ Corrective surgery for this condition was introduced in 1944. Resection

From the Department of Surgery, ${ }^{a}$ Division of Echocardiography, ${ }^{b}$ Clinic for Cardio-Vascular Surgery, ${ }^{c}$ and Department of Medical Radiology, ${ }^{d}$ University Hospital Zurich, Switzerland.

Received for publication August 1, 1995; accepted for publication Nov. 7, 1996.

Address for reprints: Rolf Jenni, MD, MSEE, Division of Echocardiography, University Hospital Zurich, Rämistr. 100, 8091 Zurich, Switzerland.

J Thorac Cardiovasc Surg 1996;112:842-4

Copyright (C) 1996 by Mosby-Year Book, Inc.

$0022-5223 / 96 \$ 5.00+0 \quad \mathbf{1 2 / 5 4 / 7 0 5 3 5}$ and end-to-end anastomosis, extended end-to-end repair, prosthetic patch aortoplasty, prosthetic interposition grafts, subclavian flap aortoplasty, ascending aorta-descending aorta bypass, and balloon angioplasty have all been used in coarctation repair and have improved survival. $^{2,3}$ The increases in late morbidity and mortality after coarctation repair are primarily related to anastomotic site complications such as recoarctation or pseudoaneurysms and associated cardiovascular disease such as bicuspid aortic valve, mitral valve lesions, ventricular septal defect, and persistent systemic hypertension and its sequelae. An unusual case of peripheral arterial embolism caused by an anastomotic site complication is presented.

Case report. A 22-year-old man was admitted to the emergency department because of acute left leg ischemia. 